FACTA UNIVERSITATIS

Series: Physical Education and Sport, Vol. 16, No 3, 2018, pp. 515 - 524

https://doi.org/10.22190/FUPES181127047C

Research article

\title{
AEROBIC ACTIVITY OF STUDENTS DURING PHYSICAL EDUCATION FITT CLASSES
}

\author{
UDC 796.727.11 \\ 796.65 \\ 796.071 .2
}

\section{Dragan Cvejić $^{1}$, Svetlana Buišić ${ }^{1}$, Nebojša Mitrović ${ }^{2}$, Sergej Ostojić ${ }^{3}$ \\ ${ }^{1}$ Faculty of Education in Sombor, University of Novi Sad, Sombor, Serbia ${ }^{2}$ Faculty of Pedagogy, University of East Sarajevo, Bijeljina, Republic of Srpska, Bosnia and Herzegovina \\ ${ }^{3}$ Faculty of Sport and Physical Education, University of Novi Sad, Novi Sad, Serbia}

\begin{abstract}
The aim of the research is to examine the volume of aerobic activities of third grade elementary school students during their physical education (PE) FITT (acronym for frequency, intensity, duration and type of activity) classes. During one PE class a pedometer was used to monitor the values students had accumulated in each planned activity. The results indicate that boys statistically accumulate more steps than girls $(2828 \pm 337$ steps, vs $2703 \pm 250$ steps $): t(89)=-1.99 ; p=.049 ; \eta 2=.04$. Most students singled out the elementary game as the most interesting activity. During the game the greatest activity volume was achieved (180 steps/min). The FITT PE class can provide one third of the daily recommended steps and 45 minutes of moderate to vigorous physical activity (MVPA) which is $100 \%$ of the class. Elementary games have the greatest potential for increasing intensity, and therefore the scope of younger school age students' activities. Class planning requires the choice of various, fun and interesting content which contributes to a high MVPA rate, to individualise activities according to students' capabilities, with appropriate work organisation contemporary inclusion of all the children into exercising process and to decrease the "loss of time" during setting up the formation and explaining simpler content.
\end{abstract}

Key words: Health-related fitness $(H R F)$; elementary school; pedometer; elementary games

Received November 27, 2018 / Accepted December 20, 2018

Corresponding author: Dragan Cvejić

University of Novi Sad, Faculty of Education in Sombor, Podgorička 4, 25000 Sombor, Serbia

Phone: +381 25412030 •E-mail: dragan.cvejic@ pef.uns.ac.rs 


\section{INTRODUCTION}

Increase of physical activity (PA) volumes among children and adolescents relates to numerous health benefits, mostly with improved cardiorespiratory (aerobic) and muscular fitness, healthier bone structure (larger bone mass, better bone structure, more potent bone strength) and more favourable weight status and adiposity (Physical Activity Guidelines Advisory Committe-PAGAC (2018). The recommendation is for children and adolescents to accumulate at least 60 minutes of moderate to vigorous physical activities (MVPA) per day (WHO, 2010; Institutes of Medicine-IOM, 2013; Okely et al., 2012; Tremblay et al., 2016). Although MVPA has a crucial significance for prevention of illness and promotion of health (Poitras et al., 2016), the majority of children cannot achieve the previously noted recommendations (Hallal et al., 2012; WHO, 2010).

School is an ideal place to increase PA volume (Bonell et al., 2014; Erwin et al., 2013; Pate et al., 2006) and to achieve 60 minutes of MVPA per day (IOM, 2013). Larger volume of PA can be achieved through increased frequency, intensity or duration of physical exercise/activity. It is very difficult to increase exercise frequency by increasing the weekly physical education (PE) class fund or increase daily PA (school sections, activity during recess and the like). Good examples are presented in comprehensive school physical activity programs (CSPAP), which emphasise the importance of PA integration during the school day at various locations within the school: (1) quality PE as the foundation, (2) physical activity during the school day, (3) physical activity before and after school, and the importance of inclusion of various members of the social community 4) school employee wellness and involvement, and (5) family and community involvement (Centers for Disease Control and Prevention, 2013; Kelder, Karp, Scruggs, \& Brown, 2014; The National Association for Sport and PE, 2008). However, in school curriculums of most of the countries, only PE classes provide the possibility for children to be active - to exercise and develop physical fitness and motor skills. As long as this is the case, larger volume of PA can be achieved only with increased intensity and/or duration of exercise in each class.

Bearing in mind that PA can be provided most through PE, schools should implement quality classes in which students will take more than $50 \%$ of the time to participate in MVPA (Sallis et al., 2012, Metzler et al., 2013; Institutes of Medicine, 2013). However, objective measurements clearly indicate that students participate in far less than $50 \%$ of PE classes in MVPA (Viciana, Martínez-Baena \& Mayorga-Vega, 2015, 2016; McKenzie et al., 2006; Metzler et al., 2013). Even in the best circumstances, a PE class can provide 10-20 minutes of MVPA (IOM, 2013). Obviously, there is a need for more efficient use of PE classes.

The FITT program (acronym for frequency, intensity, duration and type of activity) is a comprehensive program for more efficient use of PE classes with younger pupils (Cvejić \& Ostojić, 2017). The ideas for designing the program derive from PE for Lifelong Fitness: The Physical Best Teacher's Guide (Ayers \& Sariscsany, 2011) and Fitness for Life (Corbin \& Le Masurier, 2014). The goal of the FITT program is to improve the components of health-related fitness. In order to improve the components of fitness (aerobic fitness, muscular fitness and flexibility), it is necessary to practice in the development zone (Cvejić \& Ostojić, 2017), which implies individualizing exercises according to the abilities and preferences of the students, and continuously increasing the load (intensity or duration) of physical exercises and/or activities. The program is in line with the study of Sallis and associates (Sallis et al., 2012), which means that it is the Health Optimizing PE or HOPE. The purpose of the FITT program is to provide students with knowledge, skills, abilities and attitudes to be physically active throughout their 
whole lives. It includes a curriculum and teaching lessons focused on physical activity and health-related fitness.

The choice of teaching content (exercises and activities) is one of the key components in the FITT program. Just as recommended by Metzler and associates (2013), content is selected which can provide a high MVPA rate. In the FITT program, these are the contents that, with their intensity and duration, contribute to the development of aerobic fitness, muscle fitness or flexibility (depending on the outcome of the class) (Cvejić \& Ostojić, 2017). Selected content should provide the opportunity for each student to experience success. If they succeed, it is more likely that they will continue with the activity (Constantinides \& Silverman, 2018). Also, it must be fun and interesting. Fun and enjoyment in class can affect the development of positive attitudes toward physical activity (Silverman, 2017). If students are not motivated during PE class, if their work in class is a humiliating experience or, if they are bored, they will form a negative attitude toward PE (Ntoumanis, 2002). Students will not participate willingly and the intensity of the work will be lower. It is also recommended for students of this age to be provided with developmentally appropriate activities, minimizing the potential risks of overtraining and injuries and ensuring their enjoyment through participation in a wide range of physical activities (PAGAC, 2008). Therefore, the FITT program selects entertaining, interesting and varied content appropriate to the psycho-physical abilities and interests of students.

Even if the content is entertaining, interesting and appropriate, the active time (duration) of the exercise is lost if the organization of the work does not include all students (e.g. while 4 students perform the task, the others are standing in line and waiting, and they can be given a worksheet with individual tasks of varying difficulty) or the teaching methods "quench" the exercise process (e.g., too much time spent on clarifying simple content even though the content can be illustrated.) When planning the classes in the FITT program, it should kept in mind that all the students are engaged simultaneously in the activities.

The main objective of this research is to examine the scope of physical activities of third grade primary school students during a FITT PE class. Furthermore, one FITT class directed to the development of aerobic fitness is presented.

\section{METHODS}

This is a transferal type of research, and it was realized during a PE class, in October 2015, in four departments of different elementary schools in Sombor, R. of Serbia.

\section{Participants}

Participants are third-graders (age of $9.14 \pm .33, \mathrm{~N}=89$, female 44 ) included in the project of health-related fitness improvement (FITT program). The research was conducted in line with the Helsinki Declaration directives, and according to the approval of the University of Novi Sad - Faculty of Sport and Physical Education.

\section{Measuring instruments and organization of measurements}

The level of the students' physical activity was estimated using a pedometer OMRON HJ-320. The pupils were given pedometers before the class, and fitted them on their chests ("holder around the neck"). Along the sidelines of the PE gym, measuring points 
were clearly marked and numbered. Over the course of the class, students have, multiple times, come to a measuring point where the values from the pedometer displays were entered. Values were recorded at the beginning of the class, after the warm-up, after each of the 8 two-minute program activities planned in the central part of the class (jumping rope, running around the court, hand dribble, foot dribble, swimming - imitation, cycling imitation, roller skating-imitation and elementary game: Line tag), and at the end of the class after a cooling-off period.

\section{Outcomes and description of the class}

The following learning outcomes were determined: students

- in the cognitive domain (a) appoint activities which develop aerobic fitness and which can be performed in their spare time, (b) use a pedometer in order to determine the number of steps, (c) know the daily recommended number of steps

- in the affective domain (a) rank pleasure by participating in various aerobic activities, (b) show personally acceptable social behavior, (c) respectfully accept corrective feedback from teachers, (d) actively participate in class activities

- in the psychomotor domain (a) hand and foot dribble with the variation of the movement speed, (b) move within the area with a change of direction and speed, (c) connect two rope jumps.

For the purpose of a warm-up, the elementary game "Patrolman" (Appendix A) was organized for a duration of 4 minutes and a complex of 10 fitness exercises lasting 5 minutes. A special feature of the FITT program is that fitness (formation) exercises and most activities are not realized upon the number of repetitions but upon the duration (in this case 30 second/exercise). Each student stops the exercise/activity when he/she does not feel able to complete it. This is one of the ways to adjust the practice to an individual. Time was not lost either for setting up a formation (free formation used), or for explaining the exercise. Exercises are selected before the class and are appropriated to age and group. The students mimicked the teacher who performed every exercise and explained which muscle groups they were useful for. Various aerobic activities (previously mentioned) were performed in the main part of the class for 120 seconds. Although the FITT program insists on short-term intensive activities lasting 3 to 4 minutes in aerobic fitness development (Cvejić \& Ostojić, 2017), the author of this research estimated that such a timeframe of the planned activities would lead to a downfall in student motivation, and a consequent decrease in the intensity and volume of activity. After each activity, there was a 45 -second break for rest, registration of the results from a pedometer display and preparation for the next activity. During the performance of the activities, the students were orally motivated, cheered and praised. The end of the main part was used to achieve valuable outcomes in the cognitive and affective domain through questions and important notifications (e.g., what are all the aerobic activities in which you have had the opportunity to participate in today's class? Do you know some other aerobic activities? Which aerobic activity is your favorite? Have you learned to read the number of steps you have taken on the pedometer?) For the cool-down, 1 minute of light aerobic activity was planned - walking freely in the gym, and then five static stretching exercises for a total duration of 5 minutes. 


\section{Appendix $A$}

\section{Elementary game "Patrolman"}

Description: the students take one ball (volleyball) and hand dribble it while walking easily in free formation. The teacher wears two skittles. When the teacher lowers them to a distance of $60 \mathrm{~cm}$, by hand, as a patrolman signals from which side the students must run the ball through the "crossroads". Students must be patient in traffic so they do not run into each other - a traffic accident. When they pass through the "crossroads", they dribble the ball as they want. The teacher then places the skittles at another place in the gym. In each subsequent repetition, the students increase the speed of movement while dribbling - but not at the crossroads (1. Walk a little faster and dribble the ball; 2 . Run lightly and dribble the ball).

\section{Statistical analysis}

Data obtained by recording in the class were registered into the statistical package of SPSS ${ }^{\circledR} 20.0$ (Statistical Package of Social Sciences for Windows, Inc., Chicago, IL), after which the following variables were formed: Warm Up, Jumping rope, Running around the Court, Hand dribble, Foot dribble, Swimming - imitation; Cycling - imitation, Roller skating - imitation, Line tag (see Dienstmann, 2008), Central part of the class, Cooling off and Total in class) expressed through the number of steps taken. Within the descriptive statistics, the arithmetic average and standard deviation were calculated and the Kolmogorov-Smirnov distribution test was performed. The ranking of program activities realized in the central part of the class was also performed. The gender difference in the Total level of activity at PE class was established by the T-test for the two independent groups (independent samples t-test).

\section{RESULTS}

Based on the Kolmogorov-Smirnov test, we can conclude that all the variables have normal distribution (see Table 1).

Table 1 Basic descriptive statistics

\begin{tabular}{|c|c|c|c|c|c|c|c|}
\hline \multirow[b]{2}{*}{ Variables } & \multirow[b]{2}{*}{$\mathrm{T}$} & \multicolumn{3}{|c|}{ Female $(\mathrm{N}=44)$} & \multicolumn{3}{|c|}{ Male $(\mathrm{N}=45)$} \\
\hline & & $\mathrm{AS} \pm \mathrm{SD}$ & $\mathrm{KS}$ & $\mathrm{R}$ & $\mathrm{AS} \pm \mathrm{SD}$ & $\mathrm{KS}$ & $\mathrm{R}$ \\
\hline Warm-up & $10^{\prime}$ & $492.86 \pm 103.63$ & .89 & & $515.47 \pm 131.95$ & .47 & \\
\hline Jumping rope & 2 & $198.05 \pm 89.20$ & .63 & 8 & $194.64 \pm 83.53$ & .68 & 8 \\
\hline Running around court & 2 & $283.45 \pm 63.59$ & .20 & 2 & $304.87 \pm 97.28$ & .93 & 2 \\
\hline Hand dribble & 2 & $255.23 \pm 54.81$ & .71 & 4 & $263.87 \pm 68.63$ & .09 & 5 \\
\hline Foot dribble & 2 & $266.07 \pm 59.25$ & .91 & 3 & $300.18 \pm 88.55$ & .06 & 3 \\
\hline Swimming - imitation & 2 & $250.23 \pm 49.81$ & .93 & 5 & $271.73 \pm 71.59$ & .91 & 4 \\
\hline Cycling - imitation & 2 & $250.14 \pm 61.99$ & .66 & 6 & $247 \pm 94.07$ & .77 & 6 \\
\hline Roller skating - imitation & 2 & $222.11 \pm 64.32$ & .71 & 7 & $245.24 \pm 67.63$ & .99 & 7 \\
\hline Line tag & 2 & $365.86 \pm 120.83$ & .84 & 1 & $352.04 \pm 105.38$ & .67 & 1 \\
\hline Central part of the class & 29 & $2091.14 \pm 264.98$ & .97 & & $2179.58 \pm 332.02$ & .73 & \\
\hline Cooling off & 6 & $119.32 \pm 57.39$ & .83 & & $133.58 \pm 87.06$ & .71 & \\
\hline Total in class & 45 & $2703.32 \pm 249.69$ & .81 & & $2828.62 \pm 336.58$ & .94 & \\
\hline
\end{tabular}

T- activity duration in minutes; $\mathrm{R}$ - ranking from the largest to the smallest; 
While ranking the activities realized in the main part of the class, a common pattern is detected both with boys and girls. The pupils accumulated the greatest number of steps during: 1. elementary games of Line tag, 2. Running around the court; 3. Foot dribble; and the fewest in the course of 8. Jumping rope. Using the t-test of the paired samples, the difference between the first-ranked variable of the elementary game Line tag and the second-ranked Running around the court has been estimated. A statistically significant difference was found for the boys $t(45)=-2.03 ; p=.048 ; \eta^{2}=.09$; and an even more significant for the girls $\mathrm{t}(44)=-3.41 ; p=.001 ; \eta^{2}=.21$; During the student survey (Which aerobic activity is your favourite ?), 38 (84.44\%) of the boys and $39(88.63 \%)$ of the girls said that they enjoyed the elementary game Line tag the most.

Using a t-test of independent samples, a small, statistically significant, difference was found in favor of the boys in Total in class accumulated steps $t(89)=-1.99 ; p=.049 ; \eta^{2}=.04$.

\section{DISCUSSION}

The results of the study indicate that during one FITT class for the development of the aerobic fitness, the girls accumulated 2703 steps on average and the boys 2828 steps, which is almost a quarter of the recommended steps for one day (girls from 11000 to 12000 steps a day, and boys from 13000 to 15000 steps a day, see Tudor-Locke et al., 2011). If measurements are made using a pedometer, and not an accelerometer, which Adams, Johnson, and Tudor-Locke (2013) recommend for practical reasons, and due to decreased sensitivity, the minimum values should be reduced to 9000 steps/day (both for boys and for girls). According to these results, we can conclude that the participants, during one FITT class alone, accumulated almost a third of the recommended activity range in a day.

Combined with previous research findings (Scruggs et al., 2003; Scruggs 2007), Gu and associates (Gu, Chen, Jackson \& Zhang, 2018) concluded that intervals of 58 to 63 steps/minute (580 to 630 steps/10 minutes) accurately point to MVPA in $4^{\text {th }}$ to $6^{\text {th }}$ grade elementary school students. Consequently, the realized activities in the main part of the class are of high intensity. In particular, the elementary game Line tag during which the students accumulated the greatest number of steps (180 steps/minute) is particularly distinguished. It is interesting, based on the results of the survey, what they enjoyed the most during this game. Although the elementary game was realized as the last activity in the main part, in comparison to all other activities, a statistically significant difference was observed in the number of steps achieved by both boys and girls. Students of a young school age like activities which are fun and interesting. The game Line tag is one of those. It is a cooperative game - the children are working together to escape from the veins (Dienstmann, 2008). It has been proven that games motivate students (Gimenez, Valenzuela \& Casey, 2009), which was also confirmed in this research.

For achieving a large amount of aerobic activity during just one PE class, it was significant to increase the active exercise time. This active exercise time depends not only on content selection, but also on work organization. The children did not wait in lines, but at the same time they were all engaged in the realization of the tasks, each according to their own abilities (they chose the activity tempo on their own and rest when they were tired). It may be a disadvantage that in such an organization of work the teacher is not able to simultaneously monitor and correct the children during, for example hand or foot 
dribbling. As a counter argument we can state that the teacher should contribute to the creation of a broad base of motion and movement, which is achieved by various repeated activities. Specialization, according to personal wishes, should be left to experts in higher grades of elementary school or trainers in sports clubs. While training forms of movement, educators need to adapt their requests to children, tolerate the discrepancies and support the freedom of self-expression (Sabo, 2013); the same goes for teachers.

The results of this research, although statistically less significant, $p=.049 ; \eta^{2}=.04$, indicate that during a PE class, boys are more active than girls. This is in contrast to the results of the research carried out byby Brusseau et al. (Brusseau et al., 2011) in which the daily physical activity pattern was tested on a sample of 400 boys age $9.6 \pm .7$ years and 429 girls age $9.5 \pm .7$. It has been concluded that boys, in relation to girls, are more active in most daily activities (on vacation, during lunch, out of school, at school and at the total daily level), except during PE classes. The lack of gender difference at PE classes, have been linked to the fact that it is the only place where boys and girls perform identical activities. The statistically small difference that has emerged in favor of the boys in our research is the result of the work organization. The children were left with the possibility to move as much as they wanted in a given time period and were not limited by the length of the distances they were supposed to cross. This went in favor of the boys who are at any rate more physically active.

A comparison with similar research is not entirely possible due to various contents planned during a PE class. Judging by the results of this study, the average number of steps taken during a 45-minute class (girls 60 steps/minute, boys 63 steps/minute) is significantly higher than in similar studies: boys 49 steps/minute, girls 46 steps/ minute (Brusseau et all, 2011); - boys 48 steps/minute, girls 47 steps/minute (Tudor-Locke, Lee, Morgan, Beighle, \& Pangrazi, 2006).

According to the aforementioned conclusions of $\mathrm{Gu}$ and associates ( $\mathrm{Gu}$, Chen, Jackson \& Zhang, 2018) that the interval of 58-63 steps per minute is considered moderate to vigorous PA, we can point out that during 45 minutes, the duration of one class, an average of 45 minutes of MVPA was achieved.

Hence, during the PE class boys statistically accumulate more steps than girls. This study is a confirmation of the well-known results of previous studies that boys are more physically active at this age.

Regardless of the gender of younger school age children, elementary games have the greatest potential for increasing intensity, and thus the extent of students' activity. PE classes should be fun and not mentally exhausting (Dienstmann, 2008). Fun is the primary reason that triggers a child's physical activity (Blankenship, 2008). The recommendation is for teachers to continue with elementary game practice during each PE class.

\section{CONCLUSION}

FITT PE class for the development of aerobic fitness for younger school age children can provide one-third of the recommended range of daily activities, 45 minutes of which are moderate to vigorous (100\% of class). How? It is necessary to

- select the activities which contribute to a high MVPA rate (Metzler et al., 2013)

- offer various activities; there is a higher probability they would suit individual students' tendencies and interests, therefore creating the assumption that each student feels competent (successful) 
- plan fun and interesting activities which contribute to greater joy in the class

- individualize activities according to abilities as much as possible; students interrupt an activity when they cannot complete it fully or perform a substitute task which fits their capabilities

- include simultaneously all the children in the exercise process with adequate work organization (no useless waiting in lines, all the student are active during the class; when they are not actively included in the task they exercise individually according to a prepared worksheet containing tasks of various "difficulty")

- decrease "time loss" during setting up formation and explanation of simpler activities; simpler activities need to be illustrated.

The knowledge and skills of a PE teacher are extremely important in the creation of an active PE class.

\section{LIMITATIONS}

Considering the pedometer is used to stimulate physical activity (Gu \& Solmon, 2016) that is, as a motivational means for increasing the scope of physical activity, it is possible that the high values achieved during one PE class are partly the consequence of its use.

\section{REFERENCES}

Ayers, S.F., \& Sariscsany, M.J. (2011). Physical education for lifelong fitness: the physical best teacher's guide. Human Kinetics.

Adams, M.A., Johnson, W.D., \& Tudor-Locke, C. (2013). Steps/day translation of the moderate-to-vigorous physical activity guideline for children and adolescents. International Journal of Behavioural Nutrition and Physical Activity, 10(1), 49.

Blankenship, B.T. (2008). The psychology of teaching physical education: From theory to practice. Holcomb Hathaway.

Bonell, C., Humphrey, N., Fletcher, A., Moore, L., Anderson, R., \& Campbell, R. (2014). Why schools should promote students' health and wellbeing. British Medical Journal, 348(7958), 3078.

Brusseau, T.A., Kulinna, P.H., Tudor-Locke, C., Ferry, M., Van Der Mars, H., \& Darst, P.W. (2011). Pedometer-determined segmented physical activity patterns of fourth-and fifth-grade children. Journal of Physical Activity and Health, 8(2), 279-286.

Centers for Disease Control and Prevention. (2013). Comprehensive school physical activity programs: A guide for schools. Atlanta, GA: US Department of Health and Human Services.

Constantinides, P., \& Silverman, S. (2018). Cypriot urban elementary students' attitude toward physical education. Journal of Teaching in Physical Education, 37(1), 69-77.

Cvejić, D., \& Ostojić, S. (2017). Effects of the FITT program on physical activity and health-related fitness in primary school age children. Facta Universitatis, Series Physical Education and Sport, 15(3), 437-451.

Deci, E.L., \& Ryan, R.M. (1985). Intrinsic motivation and self-determination in human behavior. New York: Plenum.

Dienstmann, R. (2008). Games for motor learning. Human Kinetics.

Erwin, H., Beighle, A., Carson, R.L., \& Castelli, D.M. (2013). Comprehensive school-based physical activity promotion: A review. Quest, 65(4), 412-428.

Gimenez, A. M., Valenzuela, A.V., \& Casey, A. (2009). What are we being told about how to teach games? A three-dimensional analysis of comporative research into different instructional studies in physical education and school sports. Revista Internacional de Ciencias del Deporte, 6(18), 37-56.

Gu, X., Chen, Y.L., Jackson, A.W., \& Zhang, T. (2018). Impact of a pedometer-based goal-setting intervention on children's motivation, motor competence, and physical activity in physical education. Physical Education and Sport Pedagogy, 23(1), 54-65. 
Gu, X., Chang, M., \& Solmon, M. A. (2016). Physical activity, physical fitness, and health-related quality of life in school-aged children. Journal of Teaching in Physical Education, 35(2), 117-126.

Hallal, P.C., Andersen, L. B., Bull, F.C., Guthold, R., Haskell, W., Ekelund, U., \& Lancet Physical Activity Series Working Group. (2012). Global physical activity levels: surveillance progress, pitfalls, and prospects. The Lancet, 380(9838), 247-257.

Institute of Medicine-IOM. (2013). Educating the student body: Taking physical activity and physical education to school. Washington, DC: The National Academies.

Kelder, S.H., Karp, G.G., Scruggs, P.W., \& Brown, H. (2014). Chapter 1 setting the stage: Coordinated approaches to school health and physical education. Journal of Teaching in Physical Education, 33(4), 440-448.

McKenzie, T.L., \& Lounsbery, M.A. (2013). Physical education teacher effectiveness in a public health context. Research Quarterly for Exercise and Sport, 84(4), 419-430.

McKenzie, T.L., Catellier, D.J., Conway, T., Lytle, L.A., Grieser, M., Webber, L.A., et al. (2006). Girls' activity levels and lesson contexts in middle school PE: TAAG baseline. Medicine and Science in Sports and Exercise, 38, 1229-1235.

Metzler, M.W., McKenzie, T.L., van der Mars, H., Barrett-Williams, S.L., \& Ellis, R. (2013). Health optimizing physical education (HOPE): A new curriculum for school programs-Part 1: Establishing the need and describing the model. Journal of Physical Education, Recreation \& Dance, 84(4), 41-47.

National Association for Sport and Physical Education. (2008). Comprehensive school physical activity programs (Position statement). Reston, VA: Autonomous Edition of Author.

Ntoumanis, N. (2002). Motivational clusters in a sample of British physical education classes. Psychology of Sport and Exercise, 3, 177-194.

Okely, A., Salmon, J., Vella, S., Cliff, D., Timperio, A., Tremblay, M., et al. (2012). A systematic review to update the Australian Physical Activity Guidelines for Children and Young People. Report prepared for the Australian Government Department of Health. Retrieved on June 15, 2018 at the World Wide Web: https://www.health.gov.au/internet/main/publishing.nsf/content/F01F92328EDADA5BCA257BF0001E720D/ \$File/SR-APAGCYP.pdf

Pate, R.R., Davis, M.G., Robinson, T. N., Stone, E. J., McKenzie, T.L. \& Young, J.C. (2006). Promoting physical activity in children and youth a leadership role for schools: A scientific statement from the American Heart Association Council on Nutrition, Physical Activity, and Metabolism (Physical Activity Committee) in collaboration with the councils on Cardiovascular Disease in the Young and Cardiovascular Nursing. Circulation, 114(11), 1214-1224.

Payne, V.G. \& Morrow, J.R., Jr. (2009). School physical education as a viable change agent to increase youth physical activity. The President's Council on Physical Fitness and Sports Research Digest, 10(2), 1-8.

Physical Activity Guidelines Advisory Committee. (2008). Physical Activity Guidelines Advisory Committee Report. Washington DC: U.S. Department of Health and Human Services. Retrieved on January 10, 2012 at the World Wide Web: http://www.health.gov/paguidelines/Re- port/pdf/CommitteeReport.pdf

Physical Activity Guidelines Advisory Committee. (2018). Physical Activity Guidelines Advisory Committee Scientific Report. Washington, DC: U.S. Department of Health and Human Services. Retrieved on August 15, 2018 from the World Wide Web: https://health.gov/paguidelines/second-edition/report/pdf/PAG_ Advisory_Committee_Report.pdf

Poitras, V.J., Gray, C.E., Borghese, M.M., Carson, V., Chaput, J.P., Janssen, I., et al. (2016). Systematic review of the relationships between objectively measured physical activity and health indicators in school-aged children and youth. Applied Physiology, Nutrition, and Metabolism, 41(6), 197-239.

Sabo, E. (2013). Methods of PE of pre-school children (Theory and practice). Novi Sad: Autonomous Edition of Author.

Sallis, J.F., McKenzie, T.L., Beets, M.W., Beighle, A., Erwin, H., \& Lee, S. (2012). Physical education's role in public health: Steps forward and backward over 20 years and HOPE for the future. Research Quarterly for Exercise and Sport, 83-125.

Scruggs, P. W. (2007). Quantifying activity time via pedometry in fifth-and sixth-grade physical education. Journal of Physical Activity and Health, 4(2), 215-227.

Scruggs, P. W., Beveridge, S.K., Eisenman, P.A., Watson, D. L., Shultz, B.B., \& Ransdell, L.B. (2003). Quantifying physical activity via pedometry in elementary physical education. Medicine and Science in Sports and Exercise, 35(6), 1065-1071.

Silverman, S. (2017). Attitude research in physical education: A review. Journal of Teaching in Physical Education, 36(3), 303-312. 
Tremblay, M. S., Carson, V., Chaput, J.P., Connor Gorber, S., Dinh, T., Duggan, M., et al. (2016). Canadian 24-hour movement guidelines for children and youth: an integration of physical activity, sedentary behaviour, and sleep. Applied Physiology, Nutrition, and Metabolism, 41(6), 311-327.

Tudor-Locke, C., Craig, C.L., Beets, M.W., Belton, S., Cardon, G.M., Duncan, S., et al. (2011). How many steps/day are enough? For children adolescents. International Journal of Behavioural Nutrition and Physical Activity, 8, 78.

Tudor-Locke, C., Lee, S.M., Morgan, C.F., Beighle, A., \& Pangrazi, R.P. (2006). Children's pedometerdetermined physical activity during the segmented school day. Medicine and Science in Sports and Exercise, 38(10), 1732-1738.

Viciana, J., Martínez-Baena, A., \& Mayorga-Vega, D. (2015). Contribución de la educación física a las recomendaciones diarias de actividad física en adolescentes según el género; un estudio con acelerometría (Contribution of physical education to the daily recommendations of physical activity in adolescents according to gender; a study with accelerometry). Nutricion Hospitalaria, 32(3), 1246-1251. In Spanish

Viciana, J., Mayorga-Vega, D., \& Martínez-Baena, A. (2016). Moderate-to-vigorous physical activity levels in physical education, school recess, and after-school time: Influence of gender, age, and weight status. Journal of Physical Activity and Health, 13(10), 1117-1123.

World Health Organisztion-WHO. (2010). Global recommendations on physical activity for health. Geneva: World Health Organization. Retrived on June 10, 2018 at the World Wide Web: https://www.who.int/ dietphysicalactivity/global-PA-recs-2010.pdf

\section{AEROBNA AKTIVNOST UČENIKA NA FITT ČASU FIZIČKOG VASPITANJA}

Cilj istraživanja je ispitivanje obima aerobnih aktivnosti učenika trećeg razreda osnovne škole na FITT (akronim za frekvenciju, intenzitet, trajanje $i$ tip) času fizičkog vaspitanja. Na jednom času fizičkog vaspitanja $(F V)$ su pedometrom snimane vrednosti koje su učenici akumulirali u svakoj planiranoj aktivnosti. Rezultati ukazuju da dečaci statistički više akumuliraju koraka od devojčica (2828 \pm 337 koraka, naspram $2703 \pm 250$ koraka): $t(89)=-1.99 ; p=0.49 ; \eta 2=0.04$. Većina učenika izdvaja elementarnu igru kao najzanimljiviju aktivnost. Tokom igre je ostvaren najveći obim aktivnosti (180 koraka/minuti). FITT čas FV može da obezbedi trećinu preporučenih koraka u toku jednog dana $i$ 45 minuta umerenih do visoko intenzivnih fizičkih aktivnosti (UVIFA) što je 100\% časa. Elementarne igre imaju najveći potencijal za povećanje intenziteta, a time i obima aktivnosti učenika mlađeg školskom doba. Pri planiranju časa neophodno je izabrati raznovrsne, zabavne i zanimljive sadržaje koji mogu da doprinesu visokoj stopi UVIFA, individualizovati aktivnosti prema sposobnostima učenika, organizacijom rada istovremeno uključiti svu decu u proces vežbanja i smanjiti „gubitak vremena" prilikom uspostavljanja formacije i pojašnjavanja jednostavnih sadržaja.

Ključne reči: fizička forma povezana sa zdravljem, osnovna škola; pedometer, elementarne igre 